\title{
HUELLAS QUE PASAN, IMÁGENES QUE PESAN \\ El imaginario-archivo de la diáspora laosiana en Argentina
}

\author{
Marcela Landazábal-Mora ${ }^{1}$
}

Como torbellinos de arena levantados por el viento que pasa, los seres vivos dan vueltas sobre sí mismos, suspendidos por el gran soplo de la vida.

HENRI BERGSON, La evolución creadora.

\section{Presentación ${ }^{2}$}

Entre septiembre de 1979 y enero de 1980, Argentina recibió 293 familias refugiadas laosianas procedentes de campos de refugiados de Tailandia. El gobierno del Proceso de Reorganización Nacional, encabezado por la Junta Militar, ofreció en julio de 1979 recibir 5 mil refugiados "indochinos" ante la conferencia convocada por las Naciones Unidas en Ginebra y así solventar el drama del Sudeste Asiático. Durante el mismo año, la Comisión Interamericana de Derechos Humanos $\mathrm{CIDH}$, a petición del presidente estadounidense Jimmy Carter, decidió hacer una visita de inspección para atender las denuncias por violación a los Derechos Humanos y desaparición de personas bajo la dictadura. La recepción de familias refugiadas laosianas se conformó bajo una estrategia de exposición política ante la comunidad internacional, donde el gesto humanitario buscó revocar las denuncias imputadas por exiliados argentinos desde diferentes países.

\footnotetext{
${ }^{1}$ Universidad del Magdalena, Colômbia. Email: mlandazabalm@gmail.com ORCID id: https://orcid.org/0000-0001-6867-3242

${ }^{2}$ Este análisis tiene como antecedente el proyecto de investigación doctoral "Lo que resiste entre el exilio... Una genealogía de la diáspora laosiana en Guayana Francesa y Argentina", realizado entre el 2015-2019, donde se llevó a cabo un riguroso seguimiento de la diáspora laosiana en América Latina a partir de los dos entornos mencionados. Una deriva que quedó apenas formulada, y que el presente texto pretende profundizar, corresponde aun reflexión sobre la importancia del archivo laosiano como posibilidad -porque es ausente- en Argentina.
} 
Ambos acontecimientos se hacen coincidentes en el entramado de la Guerra Fría, no obstante, su inscripción en la memoria social argentina ha sido paralela. A partir del manejo mediático y oficial que recibieron estos exilios convergentes, el de Argentina por su expulsión y el de Laos por su recepción, se comprende que el uso de la imagen pública fue central a la hora de situar actores y acontecimientos, y sobre todo, perfiló narrativas definidas del pasado de dictadura en el país del Cono Sur. Al exilio argentino lo acompaña la sombra de los desaparecidos y los detenidos torturados. Al exilio laosiano lo sostiene la figura espectral de los refugiados de guerra del Sudeste Asiático: 'un ente masivo sin rasgos propios y siempre expuesto a la extinción'. De ahí la necesidad de posibilitar la construcción de su archivo en tanto reconocimiento capaz de imaginar un 'nuevo sujeto' situar esa 'otra' presencia activa en la sociedad argentina.

La presente reflexión reconstruye un imaginario-archivo donde se rastrea la manera en que los refugiados laosianos produjeron presencias que participan de un pasado contingente; el cual, incluso opacado, debe ser nombrado. Aquí, la nominación ejerce un poder político y simbólico rotundo en el enunciado y el reconocimiento en la memoria social. Una cosa es 'el pasado violento de la dictadura', y otra, 'la violencia en el Sudeste Asiático' como pasado; ambas se imaginan en tesituras diferentes. La primera, en el contexto latinoamericano ha requerido análisis constante sobre las sombras que activan una memoria vigente. En cambio, la segunda parece una condición estructural de las sociedades que habitaron una geografía específica en tiempos de la Guerra Fría. A partir de ello, se puede comprender por qué este archivo nuevo no posa sobre la comunidad laosiana específicamente asentada en el territorio argentino, se sitúa más bien en la diáspora laosiana y teje una historicidad dialogante con otros espacios donde inciden diferentes actores políticos internacionales y diferentes geografías interconectadas.

Surgen algunos interrogantes sobre el caso laosiano: ¿Cómo imaginar el archivo de una presencia que no tiene rastros reconocidos?; ¿Cómo definir el rastro?; ¿Cómo consolidar la memoria documental de presencias "sin historia”?; ¿Por qué toda presencia social, todo “grupo nuevo" requiere documentación que testifique su permanencia?; ¿Pensar el archivo abre espacio para seguir el tenue rastro de los exilios dispersos, de las diásporas? 
Para responder tales cuestionamientos y caracterizar el archivo de los refugiados laosianos como imaginario-archivo, el presente escrito plantea tres ejes que cuestionan la novedad que implica esta presencia en Argentina. El primero aborda una breve distinción entre el archivo oficial argentino y la conformación de archivo de una comunidad en diáspora.

En consecuencia, el segundo apartado reflexiona sobre la siguiente contraposición entre archivo oficial de dictadura encubierto, frente a un archivo oficial laosiano inexistente. El archivo de dictadura es un horizonte abierto donde la exigencia de todo discurso colectivo está ávida de verdad. Cuando sale a la luz, tras décadas de encierro, desentraña las demandas políticas al pasado de represión y busca, antes que rescatar la información, delatar sus formas encubiertas. Es un archivo que convoca sobre la base de un pasado común. Ante ello, la comunidad laosiana inscribe un evidente contraste por el escaso seguimiento a su proceso. El rescate del pasado laosiano no se manifiesta como denuncia; no es una urgencia, ni para la comunidad de la diáspora, ni para la sociedad argentina. Entonces, pensar su imaginario-archivo atiende la necesidad de reconstruir estamentos de lo común sin la denuncia como garante de visibilización. Esta otra orientación política busca resituar un entramado más amplio, ya no de las urgencias, sino de las ausencias.

El tercer apartado sitúa al refugiado laosiano como novedad en Argentina, partiendo de la revisión del estereotipo generado por el discurso oficial y los medios de prensa. Los refugiados han estado como comunidad rizoma -al modo poético-político de Édouard Glissant- tejiendo una identidad de diáspora, expandida pero poco profunda, aún 'incipiente' para la historia argentina. Aquí, la imagen de la niñez se revisa en tanto referente icónico de la adaptación a condición de un futuro impuesto por el discurso de prensa y el oficial. Hay una estrecha relación que asocia al refugiado con cierto infantilismo, aquí también la imagen del infante refugiado dispone el consenso colectivo para pensar un futuro de acogida basado en la asistencia. Los laosianos aparecen como refugiados en Argentina, y en América Latina, a partir de una alfabetización binaria oriente/occidente donde son asumidos como alteridad extrema.

\section{Distinciones para el archivo de una comunidad en diáspora}


En la diáspora, hay un considerable condensación geográfica y temporal. Los traslapes entre pasados múltiples, vinculados a opciones de futuro disonantes, configuran el presente de una comunidad dispersa cuyo núcleo común es un trauma por la guerra y por el desarraigo. El tiempo presente depende del pasado atomizado en múltiples trayectos, desorientado y contingente. Esto contrasta con la percepción de pasado en sociedades que han permanecido en un mismo territorio atravesado por un conflicto donde, lo común no sólo es el trauma de la violencia, sino la historicidad compartida en la misma geografía, incluso con los propios desplazamientos internos. Aquí el imaginario de nación-estado contiene. En cambio, el problema en la diáspora consiste en desarrollar la capacidad de imaginar una coincidencia entre el pasado común y el futuro contingente; una suerte de memoria dislocada pero funcional (espacios geográficos distantes, condiciones de vida variadas, políticas reguladoras y diversas estrategias de supervivencia jurídica).

Por lo tanto, imaginar un archivo en contexto de diáspora exige organizar una gramática del tiempo vinculada a los espacios y tiempos múltiples; dar imagen a lo 'imposible'. El imaginario-archivo coloca en relación lo no visto con lo recurrente; evalúa los imaginarios y las narrativas sostenidas como verdades compartidas. Esta posibilidad de imaginar es una capacidad crítica comprometida con el ahora, no refiere a una ocurrencia fortuita sobre la historia, ni se limita a sus mitografías, en cambio, habilita otros 'posibles' sobre el pasado que dota de sentido a 'los presentes'. ${ }^{3}$ En esta tesitura, la imaginación en tanto praxis, en tanto saber, es sustento del aparecer político.

Ahora bien, imaginar un archivo exige cuestionar sus formas de visibilización, organización, construcción y aprovechamiento, pero sobre todo, su localización y posibilidad de rastreo. El archivo tiene una estrecha relación con el espacio simbólico de algunos rastros físicos, y otros que se han desmaterializado; es una suerte de camino, pero se confunde frecuentemente con el vestigio. En este sentido, el imaginario-archivo cuestiona el vacío como soporte de pasado y configura otras cartografías para la memoria; conforma un sistema coherente con lo que Michel Foucault llama heterotopología -una

\footnotetext{
${ }^{3}$ Tomo el término en el sentido de Arturo Escobar, como base para convocar una imaginación que derroque la marca de 'lo real' como al estático. Véase (Arturo Escobar, 2018)
} 
ciencia de los lugares que la sociedad acondiciona en sus márgenes, en las zonas vacías que le rodean. ${ }^{4}$

En contraste, el archivo oficial argentino es un estamento central de visibilización política y ha sido recurrentemente cooptado por las formas oficiales de administrar la información 'para la historia'. Por ello tiene consecuencias determinantes en la reconstrucción de la memoria social. ${ }^{5}$ Funciona como fuente de conocimiento porque se administra como fuente de convencimiento. Por ello presenta el doble acondicionamiento abismal; donde el acontecimiento se desvanece de un tiempo que podría retenerlo antes que las estructuras, en las cuales se afianza, desaparezcan. Es siempre un dispositivo agónico que actualiza la capacidad (el poder) del presente para sostener sus pasados, y esto implica un valor político, pues no pertenece a la historia oficial, ni a las instituciones, sino a la facultad de instituir una organización del tiempo. De esta manera se presenta como estrategia, un conjunto de técnicas instrumentadas para dar forma al tiempo a través de la delimitación (documentación) de sujetos, actores y escenarios en aparente riesgo de desaparición, o con una expresa necesidad por ser resguardados.

En vez de tensar presente y pasado, el archivo oficial coloca en diálogo las administraciones de la imaginación (y la imagen) de un espacio para el tiempo. Un primer interrogante a las administraciones gubernamentales argentinas consiste en indagar qué consenso permitió determinar la posibilidad o imposibilidad de un archivo para los refugiados laosianos; sobre qué bases el pasado de los contingentes perdió relevancia; e incluso, se puede cuestionar a qué se le llamó pasado cuando llegó la transición democrática. ${ }^{6}$

\footnotetext{
${ }^{4}$ Esta noción parte de las distinciones que el autor propone sobre la heterotopía, ésta señala la reflexión acerca de los lugares "absolutamente otros", que a diferencia de la "utopía" reservada para los espacios inexistentes, indica un principio de relación basado en la extrañeza, en el contacto inesperado. (Foucault, 2002) y sobre lo heterogéneo del archivo véase del mismo autor (Foucault, 2010).

${ }^{5}$ De ahí la dificultad para separar la memoria de la historia, que expresaba François Hartog. (Véase la entrevista de Renán Silva al historiador francés (Silva, 2012).

${ }^{6} \mathrm{Si}$ por pasado se toma sólo el efecto visible de la represión hacia la sociedad civil y militar local -incluso la del exilio. Para una reflexión sobre estos estamentos que definen el pasado y las pruebas de experiencia en los marcos de representación de la memoria social véase (Alejandro Castillejo, 2013: 21-40) y (Mario Rufer, 2018).
} 
En esta reflexión, el imaginario-archivo tensa la relación imagen-historia y geografía política, partiendo de la siguiente premisa: el archivo laosiano revela la capacidad política de imaginar críticamente un pasado (o los necesarios) que permita(n) configurar entornos simbólicos de futuro(s) para las comunidades al margen en Argentina, pero también, en América Latina, como son los refugiados del Sudeste Asiático.

\section{El archivo laosiano en Argentina, lo nuevo-imaginario}

El archivo de los contingentes laosianos comporta un relato posible antes de hallar sus vestigios; no existe, no hay forma de presumir sus formatos salvo por la presencia de una comunidad con gestos sutiles. En contraparte, desde el comienzo del periodo democrático la sociedad civil argentina ha hecho énfasis en sacar a la luz los archivos secretos del Proceso para revisar críticamente el pasado y así continuar una reparación de la memoria de dictadura. ${ }^{7}$ En ese espacio de inscripción, el archivo secreto tiene un cuerpo documental sancionado, mutilado y oculto, pero se presume su existencia; este requiere ser expuesto entre la comunidad local para re-imaginar los hechos o resignificarlos.

Una de las evidencias más contundentes de la acción social sobre los archivos de la dictadura consiste en la enunciación del terrorismo de Estado para cuestionar los archivos encubiertos de la dictadura (Vezetti, 2003). Aquí, la aparición estratégica de los contingentes laosianos dentro de la coyuntura de la visita de la $\mathrm{CIDH}$ puede entenderse como un factor adyacente a la estrategia argentina para manipular la opinión pública ante la comunidad internacional; esto justificaría su falta de reconocimiento. La cobertura mediática fue visible entre los años 1979 y 1982, después los refugiados laosianos quedaron sin seguimiento periodístico u oficial. Sólo, en 2012 la Dirección Nacional de Población decide organizar un informe muy breve de las características de la migración de estos contingentes. ${ }^{8}$

Con la llegada del periodo democrático que sucedió al Proceso de Reorganización Nacional el archivo pasó de ser un acervo de información prohibido, privado, cerrado a un dispositivo defectuoso, incompleto, corruptible; abierto. La demanda social lo cuestiona y

\footnotetext{
${ }^{7}$ Véase Argentina Declassification Proyect https://www.intel.gov/argentina-declassification-project

${ }^{8}$ Al respecto véase (Dirección Nacional de Población, 2012).
} 
lo mantiene vigente al traer ese pasado en tanto denuncia del presente. ${ }^{9}$ Es relevante esta condición porque también da cuenta de una sociedad en vigilia, que examina su pasado porque su memoria no puede descansar. La historia de la dictadura no tiene un relato acabado, es una herida abierta en la sociedad argentina. Y justamente la movilidad colectiva inscribe al archivo más allá del orden oficial, en el orden simbólico -lo desfasa del relato histórico y le otorga historicidad. ${ }^{10}$ En este contrapunto de valores simbólicos, la comunidad laosiana comporta una ausencia en la memoria política, pese a la cuatro décadas de presencia en Argentina.

Ante este telón de fondo, el archivo laosiano-argentino está estructurado en un vacío gubernamental y geo-político. Por ejemplo, hay un gran contraste con Estados Unidos, país que recibió la mayoría de refugiados laosianos, frente al caso argentino. En ese país la sistematización de la información de refugiados apoyó la organización de los mecanismos de reparación internacional post-Vietnam; el balance entre el seguimiento mediático y el seguimiento oficial formulaba una estrategia de imagen consolidada, resguardada, respaldada. En cambio, en Argentina los indicios visibles de los refugiados sólo se pueden rastrear en las fuentes de prensa que difundían la mirada oficial. Este hecho da cuenta de la importancia otorgada a la percepción internacional y la manipulación de la información en la comunidad local. En aquellos años Argentina ocupaba el primer lugar en circulación de prensa en América Latina. A ello se suma la adherencia de los medios impresos más importantes del país con el 'Proceso'. La Nación publicaba diariamente, y aunque figuró como el cuarto periódico en volumen de circulación nacional, junto con Clarín fueron reconocidos como los principales adherentes a la dictadura. ${ }^{11}$ Por lo tanto, se presume que la información rescatada acerca de los laosianos es alentada por la propaganda de la

\footnotetext{
${ }^{9}$ Enfáticamente esta denuncia aterriza sobre la falta de políticas públicas para manejar los archivos militares y los documentos oficiales que han sido privatizados o suprimidos de los acervos públicos. Comenta Cinthia Balé: "La prolongada falta de una política integral de preservación, tratamiento y difusión del patrimonio documental así como la ausencia de una política de acceso a la información pública convirtieron a la mayor parte de los archivos estatales en territorios marginales e inhóspitos". Véase (Balé, 2018).

${ }^{10}$ Pilar Calveiro comenta sobre la necesidad del relato histórico para fundarse en el archivo, en tanto discurso organizado. Véase (Calveiro, 2006). La memoria, en cambio, parte de la experiencia, de lo vivido, de la marca inscripta de manera directa sobre el cuerpo individual o colectivo. No obstante, el archivo también es un estamento de disputa, a quién, sobre quién, de quién, para quién la información.

${ }^{11}$ Véase (Landazábal-Mora, 2019: 61 -63).
} 
perspectiva institucional. Destacan dos derivas fomentadas desde la prensa, una sobre los refugiados del Sudeste Asiático y otra sobre los territorios de exilio:

\section{Oriental y salvaje: condiciones del refugiado laosiano}

La primera atiende a la construcción orientalista y primitiva del refugiado laosiano como una alteridad extrema, demasiado lejana. Esto se debe por una parte, a la resonancia del conflicto vietnamita en la época y por otra, a la brecha existente entre el binomio oriente/occidente como opuestos -situación agudizada por el mapa geopolítico de la Guerra Fría. A ello se suma el imaginario de nación argentina cuya base racial refiere a los migrantes blancos europeos que arribaron en barcos; en menor medida se considera el mestizaje con población nativa y otros grupos culturales (Yao, 2002). No obstante, se reconoce la importante presencia de población originaria de Japón, muy visible en Buenos Aires, apoyada más en su manifestación de clase y su aspecto blanco, en contraste con la imagen del indochino (Onaha, 1997). La siguiente nota de prensa del diario La Nación del 16 de Septiembre de 1979, titulada Plan educativo para los refugiados asiáticos, informó a la población local sobre los planes de preparación para recibir a los nuevos inmigrantes de la siguiente manera:

El aprendizaje está destinado a crearles nuevas costumbres de vida, hábitos de higiene y alimentación, así como también a impartirles las primeras nociones idiomáticas. Las autoridades del Consejo Nacional de Educación anticiparon que en dos meses los refugiados podrán armar las primeras frases en castellano y que para manejar con cierta libertad el idioma deberán estudiarlo por lo menos dos meses más.

Durante los diez días que permanecerán en Ezeiza el grupo contará con la ayuda de un intérprete vietnamita que habla laosiano y otros dos que dominan distintos dialectos.

Esta breve nota está precedida por una serie de al menos 45 notas de prensa desde julio de 1979 en el diario La Nación. Las descripciones frecuentes se ampliaron hasta el mes del desembarco del primer contingente, en septiembre. El contenido publicado a diario configuró una perspectiva sobre los refugiados del Sudeste Asiático donde no se distinguía claramente una imagen de 'lo laosiano', 'lo vietnamita' o 'lo chino' porque estaba inmerso en el conflicto vietnamita. Se hablaba de 'lo indochino' empleando una asincronía histórica como pretexto de identificación. Las descripciones están saturadas de comparaciones estereotipadas sobre los rasgos étnicos y las costumbres de las poblaciones en los campos de refugiados de Tailandia. Según la perspectiva del corresponsal y cronista Narciso 
Binayán Carmona, quien trabajó para el diario La Nación, el desconocimiento mutuo entre la comisión argentina y los refugiados era el punto de encuentro. Este desconocimiento, del que participó el gobierno del Proceso, se tradujo en oferta de un plan educativo basado en principios de adaptación a "la vida occidental civilizada", la cual buscó saldar en un periodo muy corto, el inevitable choque cultural. El 13 de septiembre de 1979, una nota del corresponsal de La Nación titulada Viajan para la Argentina los primeros refugiados asiáticos detalla:

(...) 56 hmong y un puñado de vietnamitas. Para los vietnamitas y chinos, la adaptación al vuelo no será demasiado difícil ya que conocen una cantidad de cosas de la cultura occidental y se han asomado a la sociedad de consumo. Pero para los hmong es otra cosa.

Recordemos que los hmong no conocen ni el tenedor, ni los palitos, sino sólo las cucharas. Según el uso tradicional de la cocina del Extremo Oriente todos los alimentos son preparados en trozos pequeños. ¿Será éste el caso ahora o deberán comer con la mano en el estrecho espacio del asiento del avión?

La cosa no termina ahí. En los últimos días han estado recibiendo adiestramiento con dibujos (...) sobre cómo deberán hacer el viaje. Es decir, han debido aprender a viajar sentados. (...)

Para tener más idea del asunto, imaginemos que a un occidental cualquiera, importa poco que sea de Moscú, de Los Ángeles o de Montevideo, se lo obligara a viajar la distancia Bangkok-Buenos Aires, es decir de un extremo a otro del mundo, sentado en cuclillas, que es la posición normal de nuestros nuevos compatriotas".

(...) Para los hmong, el viaje significa más que la expatriación o la emigración, implica el abandono definitivo del sueño nacional de la independencia. Un sueño por el cual lucharon valientemente años y años contra los comunistas. Hombro con hombro con una gran potencia occidental que los abandonó como a los demás pueblos indochinos. Significa también para siempre la ruptura con una cultura muy modesta que han defendido durante miles de años contra el avance arrollador de la civilización china. Es la suya y la querían.

(...) Ojalá que sean felices en nuestro país y que todas las expectativas que han depositado ante la puerta que se les ha abierto, se cumplan. Después de todo, no es el primer pueblo de perseguidos que llega a la Argentina, que esconde sus lágrimas y el dolor del destierro y rehace su vida en paz".

Este fragmento de prensa relata tres aspectos particulares. En principio el refugiado laosiano está asociado con la población hmong, una de las etnias que componía la demografía de Laos. La descripción sobre la alfabetización y la vinculación al mundo occidental resulta en una caricatura marcada por los estereotipos de un saber colonialoccidental evidente. El presupuesto racista, la anticipación descriptiva como mecanismo para 'conocer' al otro y la invitación a incluirlo en un mundo más culto, más avanzado, más 
civilizado demarcó una estructura de saber/poder que condicionó la entrada del refugiado laosiano en el territorio argentino. Los contingentes no estaban conformados únicamente por familias hmong como se presuponía. Hoy día, sólo quedan alrededor de ocho familias de dicha etnia entre la Provincia de Buenos Aires y Río Negro. La mayoría del contingente estaba compuesto por familias lao, algunas Taï, entre otras. Sin embargo, el principio descriptivo del corresponsal aplicó para todos. Para el 2017, algunas familias visitadas, durante el trabajo de campo de la investigación que alienta este artículo, en Misiones, recordaban haber sido acusadas de comer perros por ejemplo, o de llevar a cabo prácticas asociadas a la falta de pulcritud de 'los chinos'. Esas conductas de la población local argentina fueron cambiando progresivamente debido al trabajo diario de las familias laosianas. Desde hace algunas décadas han sido una minoría reconocida en Posadas tras un largo proceso de adaptación y consecución de derechos -como el de vivienda y tierras. ${ }^{12}$

En segunda instancia, la suposición del imaginario de un 'occidental promedio (argentino)', compartido con las geografías del Norte del planeta, determina una inclusión igualitaria de Argentina como un pueblo 'a nivel', determinado por las condiciones de su migración y su composición demográfica. Aquí resalta el imaginario de la tierra de migrantes, en detrimento de la población nativa argentina o la población afrodescendiente, sin duda, otro aspecto que amerita detallada revisión.

Por último, esta nota fue la única evidencia que detalla el lugar de la población hmong dentro de la Guerra Civil de Laos. La población hmong estuvo inmersa en un complejo cuadro de disputas ancestrales por determinados territorios, tras décadas de confinamiento en las montañas altas. Para la época colonial francesa y la invasión estadounidense, la fracción militar del pueblo hmong, encabezada por el general Vang Pao, encontró una coyuntura favorable para recuperar sus territorios, por lo que se definió como la fracción anticomunista frente al Pateth Lao. Estados Unidos aprovecharía esta riña interna para conformar una fuerza militar al interior de Laos y así debilitar las fracciones comunistas tanto del Pateth Lao, como del VietCong. No obstante, la mayoría de la población hmong se dedicaba a la actividad rural. En el marco de una guerra bipolar, su situación fue

\footnotetext{
${ }^{12}$ Se puede ampliar información en la descripción de trabajo de campo adelantada por la investigadora Romina Zulpo de la Universidad Nacional de Misiones. (Zulpo, 2012)
} 
determinante para inaugurar el primer gran éxodo de comunidades laosianas hacia Tailandia en 1975; seguido por miles de refugiados de otras etnias donde la población urbana cohabitaba con la rural. El resultado comentado por Binayán Carmona en el campo determinaba un visible desespero ante el cual, la promesa de una tierra de asilo, fue descrita en la parte final del texto del corresponsal.

De esta manera, la imagen de los refugiados queda abierta hacia una promesa de integración a costa de considerarlos como alteridad extrema -algo así, como un salvaje oriental, reafirmando con ello la exterioridad que representan por su procedencia y sus condiciones jurídicas y económicas. Las condiciones de alfabetización prometidas, así como otras condiciones de recepción no se cumplieron. La población laosiana fue dispersada rápidamente en las zonas rurales menos desarrolladas del territorio argentino a pocas semanas o días de su arribo. ${ }^{13}$ Los planes de educación no tuvieron un seguimiento regulado y consistente, no hubo traductores o personal capacitado para apoyar la transición de la llegada y de esta manera, la integración. El aprendizaje del idioma, la dieta y otras costumbres argentinas estuvieron a cargo de familias locales y la voluntad de las familias recién llegadas para integrarse. ${ }^{14}$

\section{La tierra prometida y la administración del exilio}

La segunda deriva contempla el fracaso institucional del gobierno argentino en tanto organismo de apoyo humanitario, anticipado por la detención del Plan de Recepción de Refugiados en $1981 .{ }^{15}$ Esto es, el desmantelamiento de la promesa de Argentina como imaginario de asilo creado ante la contingencia de la CIDH. La interrupción del proceso de recepción expuso la falta de estrategias gubernamentales para hacer efectiva la adaptación de refugiados laosianos. Esto anticipó el desinterés para sostener el seguimiento del proceso y posibilitar la construcción de un archivo oficial. Con las comunidades dispersas por el territorio argentino, la diáspora laosiana daba continuidad al proceso de atomización

\footnotetext{
${ }^{13}$ Las ciudades de destino Buenos Aires provincia, Santa Fé, Córdoba, Mendoza, La Pampa, Salta, Jujuy, Entre Ríos, Misiones y Río Negro.

${ }^{14}$ Al respecto véase (Redondo, Adriana, 1987); (Zulpo, 2012) y (Landazábal-Mora, 2019).

15 Después del sexto contingente, se comenzaron a cerrar los centros de tránsito temporal en Argentina en 1981. Ante esto, las autoridades consideraron oportuno terminar de integrar los grupos ya arribados. Véase (Landazábal-Mora, $O p$, cit).
} 
y por lo tanto, la adaptación llevó al debilitamiento de algunas prácticas tradicionales en pro de sostener una inclusión traumática, sin estrategias educativas ni procesos de transición.

El 29 de enero de 1982 Clarín publicó un informe especial titulado Qué pasa con los refugiados, donde comenta:

Del total de los refugiados laosianos en edad laboral, el índice de desocupación es del $44 \%$. Quienes tienen trabajo -en su mayoría son empleados administrativos o en servicios públicos. Quieren regresar a Laos, pero este país no los admite y las autoridades los reubican en el interior del país, desde donde emigraron hacia la Capital”. En diciembre de 1980 - 106 familias habían abandonado sus asentamientos en el interior. En el corriente mes de enero dos nuevas familias vinieron a la Capital.

De las 293 familias que llegaron inicialmente, 12 viajaron a Francia, por ejemplo, y el gobierno de París comunicó no estar dispuesto a aceptar más refugiados laosianos procedentes de la Argentina. ACNUR asistió a 80 de esas 106 familias, algunas lograron permanecer en Buenos Aires, mientras 43 familias fueron devueltas a sus lugares de trabajo en otras provincias. Los grupos familiares que permanecieron en Argentina se situaron hacia el norte, en especial en la ciudad de Posadas, ciudad colindante con Paraguay en la provincia de Misiones. Los refugiados trabajaban como obreros, metalúrgicos, mecánicos de automotores, electricistas, enfermeros, sastres o peluqueros, mientras las mujeres trabajaban algunas horas en las municipalidades o se dedicaban al hogar. En las provincias del norte, muchas mujeres comentan su dedicación a la venta puerta a puerta de ropa y algunas artesanías, para contribuir con la manutención del hogar.

Según las declaraciones de funcionarios de ACNUR la mala imagen de los laosianos no corresponde con la realidad "Piensan que los refugiados laosianos se están integrando bien al país". Esta última declaración, citada en la nota de prensa mencionada propone pensar el asunto de la integración en retrospectiva, ya no desde las políticas y estrategias gubernamentales que no se lograron, sino desde la gestión de los habitantes locales que los recibían y las estrategias construidas por los refugiados.

La integración de la comunidad laosiana al imaginario cultural argentino puede entenderse como la inclusión abrupta de una singularidad en el denso entramado social que ya componía a la nación argentina durante el gobierno del Proceso. Las estrategias 
organizadas por la propia comunidad laosiana, con el apoyo de algunas familias locales, presenta diferencias según los lugares de asentamiento. En esta multiplicidad de las formas de adaptación, de las estrategias de supervivencia y asentamiento, está localizada la importancia de construir su archivo nuevo. El imaginario-archivo abre rutas para las particularidades de su adaptación situando su imagen presente de acuerdo a los procesos disímiles que siguieron a lo largo y ancho de la geografía argentina. Aquí destaca el momento convulso de llegada, las estrategias de auto-organización, las rutas de escape de algunas familias desesperadas ante el desengaño de un imaginario de exilio contradictorio. Pero también está presente la deserción de un retorno hacia el lugar de origen. La migración laosiana escapa del imaginario argentino, no arribó en barcos y a cambio inscribe su especificidad laosiana transformando la figura del refugiado.

\section{Supervivencia sin rastro, la vida de un ser-imaginario}

Refugiado de guerra es una categoría de carácter humanitario que habilita un esquema de resguardo, salvaguardia y protección para personas víctimas de un conflicto bélico que requieren dejar su territorio originario. Sin embargo, la categoría que visibiliza también homogeniza las particularidades y conforma un ser-en-masa, metamorfoseado por las cifras y la densidad inmanejable de un problema; como la incapacidad fronteriza de las naciones vecinas para contenerlo. Los lugares habilitados para paliar 'el problema de los refugiados' se dimensionan desde instancias macro y se trabaja por medio de regulaciones efectivas sobre grandes colectividades, de ahí la importancia y la necesidad de concentrarlos en un campo de refugiados. Importa lo masivo del problema, poco el individuo; importa concentrarlo para manejarlo. En esta instancia, el cuerpo (propio y colectivo) es el gran afectado y paradójicamente, el gran desaparecido. La experiencia de uno pertenece a todos y la identidad de los innombrables es compartida.

El refugiado laosiano como imaginario, fue producido y acondicionado por instancias políticas, económicas, geográficas y mediáticas que impusieron esquemas de estereotipación. Su imagen se vinculó con la masificación de un proceso más complejo, la Guerra Civil de Laos, pero ésta fue eclipsada por la imponente Guerra de Vietnam ante la comunidad internacional. En este complejo panorama de opacidades políticas, el refugiado laosiano resulta en un actor narrado bajo estrategias de catalogación, exotización y 
exteriorización que lo hacen congruente con su condición límite; entre estar sin lugar y el anonimato.

La llegada de los refugiados laosianos a Argentina surge de la diáspora y en ello incide el núcleo bélico que origina su migración desde la Guerra Civil de Laos, el paso por el campo de refugiados y la dispersión en diferentes países del mundo. A través de esta cadena de topologías heterogéneas se comprende su trayecto. La diáspora tiene un carácter conectivo entre diferentes grupos de refugiados laosianos en el planeta, pero resguarda una memoria entre el antes y después de la dispersión; así devuelve la posibilidad de construir un mecanismo retórico, oficial, simbólico, plástico entre otros, para ser-visible; aparecer.

Esto se ha rastreado en dos pautas: a. el campo de refugiados en Tailandia como el contexto que origina la figura del refugiado laosiano y b. la narrativa de prensa construida sobre el refugiado en Argentina.

\section{El campo de refugiados; "pasar" la guerra}

Durante la Guerra Fría, Laos libró sus propias batallas por diferencias étnico-políticas agudizadas por las secuelas del colonialismo francés mientras era pieza clave en la estrategia de ataque militar estadounidense a Vietnam. Entre 1964 y 1973 el territorio laosiano había recibido más de dos millones de toneladas de bombas de parte de los aviones bombarderos de Estados Unidos. Las deplorables consecuencias de este periodo mantienen vigente la violencia en el medio rural principalmente. ${ }^{16}$ La guerra que llevaron a cabo la CIA y las tropas estadounidenses contra el comunismo del Pateth Lao fue denominada Guerra Secreta de Laos, también conocida como la Guerra Civil de Laos. De este conflicto fueron expulsadas alrededor de 50 mil personas durante la primera fase, en 1975 (ACNUR, 2000). Cerca de 10 mil personas, pertenecían a la etnia hmong.

Tailandia fue el principal receptor de refugiados por vía terrestre. Durante el periodo más crítico de la Guerra Civil de Laos, efectúo sus labores como país de primer asilo entre

\footnotetext{
${ }^{16}$ Los relatos en la prensa internacional sobre la Guerra de Vietnam consideraron a Laos un factor contingente y alterno; sólo de manera oficial los expedientes gubernamentales de Estados Unidos incluyeron revisiones sobre las misiones militares estadounidenses en territorio laosiano.
} 
1975 y 1980, al presentar la economía más equilibrada de la región. ${ }^{17}$ En aquellos años se habilitaron nueve campos para refugiados laosianos a lo largo de la frontera del Mékong con Laos. El cruce de dicha frontera se cita de manera recurrente en los relatos de los refugiados laosianos en Argentina. El río funciona como eje común de la experiencia de huida, pero también se plantea como el umbral imaginario que marca el exilio. Las estrategias, las experiencias y las formas de atravesarlo fueron muy diferentes entre sí, pero sostenían en común la promesa de la supervivencia y el posterior reencuentro con sus familias, en los campos de refugiados. Sin embargo, en aquellos entornos de aparente salvación, la experiencia de supervivencia adquirió un condicionante específico para la guerra; sería el lugar de concentración-dispersión vía la administración externa del fenómeno. Allí se inauguró la diáspora.

El comité argentino que llegó a los campos en Tailandia concentró su estrategia en la selección de "familias tipo", conformadas por un promedio de cuatro personas que contemplaran padres jóvenes e hijos pequeños. Este tipo de peticiones de los países de asilo y asentamiento impuso un esquema de improvisación insospechado para las familias refugiadas, ya que la organización social de la mayoría de etnias laosianas se disponía en clanes. Las familias laosianas generalmente estaban conformadas por de más de 10 miembros y mantenían una vida de comunidad donde la autoridad patriarcal del abuelo tenía gran peso, así como la presencia de otros miembros mayores en la familia (Dao, 1993). Los países de asilo vieron una oportunidad para suplir sus necesidades de mano de obra regulando el formato migratorio, mientras se ofrecía ayuda humanitaria. Esto también se evidencia en Francia y la Guayana Francesa, por ejemplo.

Después del trauma de la guerra y la huida en el cruce de frontera, la separación de las familias extendidas fue un quiebre irrecuperable en la memoria de los refugiados laosianos que arribaron a diferentes partes del mundo. Justamente esta experiencia tan propia del campo de refugiados exige un primer rastreo de lo inexistente como vestigio. Salvo algunos documentos muy deteriorados, el paso por este lugar es un asunto conservado en los

\footnotetext{
${ }^{17}$ El primer asilo es una categoría que resulta de la Convención de Ginebra sobre Refugiados Indochinos de 1979. Esta condición consiste en responsabilizar a un primer país de la seguridad de los refugiados, mientras un segundo ofrece el reasentamiento.
} 
recuerdos fragmentados de quienes lo vivieron. Por otra parte, el desmembramiento de la familia laosiana en los campos se percibe tan violento como la guerra. La elección de rangos etarios productivos, con hijos pequeños y la descalificación de los ancianos, amputó de manera drástica la memoria ancestral.

La salida del campo de refugiados exigió estrategias urgentes de abandono fomentadas por la extrema precariedad. Algunas personas comentan cómo cambiaron de nombre, cómo se dieron 'nuevas relaciones familiares' para encajar en las demandas de Argentina, por ejemplo, y así adquirieron nuevos apellidos y otras formas de reconocimiento oficial; porque llegaban a un lugar donde no se les conocía, más que como refugiados.

Los hermanos menores de repente fueron registrados como hijos de las hermanas mayores; las uniones impensadas por diferencias étnicas ancestrales se fundieron como estrategia de supervivencia; las familias extensivas resultaron divididas en pequeños núcleos organizados a la sombra de las disposiciones de los países oferentes. Desde aquí, la inminente diáspora se concentró en la misiva de sobrevivir y mantener la esperanza de volverse a encontrar. Algunas familias lo lograron, pero 'la integración' es un consenso imaginario de la condición de diáspora. El campo de refugiados presenta una rememoración dolorosa. En el campo confluyó la topografía de la región, el sesgo marginal con que los laosianos fueron tratados en Tailandia, las condiciones de hacinamiento que motivaron rencillas internas, entre otros factores, para hacer evidente la necesidad de reasentamiento. El campo indicó por vez primera la imposibilidad del retorno. El umbral de incertidumbre por el futuro vinculó al campo con la supervivencia.

El campo de refugiados es un dispositivo jurídico y político que mantiene en tensión los esquemas de protección y salvaguardia de la vida. Giorgio Agamben lo entiende como una "una zona de indistinción entre interior y exterior, excepción y regla, lícito e ilícito" (Agamben, 1995, 120). Es por lo tanto, una suerte de parcela jurídica del afuera que determina al refugiado de guerra como una extrañeza, porque el campo es un espacio de excepción que, habitado por una cantidad considerable de años, termina siendo regla. En su estructura provisional adaptada a topografías fronterizas no sólo se refugian los cuerpos, también se condensa la experiencia de huida de una multitud sin aparente forma. Se hace lugar memoria, donde se "refugia y cristaliza la memoria colectiva" (Nora, 2008). 
Para la comunidad laosiana en Argentina, el campo de refugiados es un silencio. ${ }^{18}$ Esta condición es materia para la reconstrucción de un archivo que documente el campo como el lugar de lo indecible, el vacío para el relato y la saturación para la memoria. Aquí también puede cuestionarse su correspondencia estratégica con el olvido.

\section{Refugiado, una imagen que pesa}

Los refugiados movilizan en su tránsito todos los esquemas de referencia jurídico-política a medida que se desplazan y con ello dan cuenta del sistema de relaciones que los vinculan o expulsan de maneras simultáneas en cada espacio de llegada. El refugiado, incorpora el indicador de frontera en su aparición y reconocimiento social; es el sujeto transgresor de la frontera misma; él mismo es frontera. Para tipificar su presencia en cada entorno de llegada se requieren herramientas de visibilización que permitan hacerlo reconocible en tanto cuerpo externo y extraño. En el caso argentino resultan clave dos maneras de identificar a los migrantes laosianos: una es $a$. la oficial gubernamental y la otra $b$. la mediática -que inscribe también un carácter de oficialidad.

\section{a. El formato sin huellas}

La información de los contingentes que partieron de Bangkok y que arribaron a Argentina se organizó a través de algunos datos generales para complementar el inventario demográfico, como instrumento jurídico y de resguardo ante organismos internacionales, por parte de las autoridades gubernamentales (Figura 1). Los primeros datos se capturaron en un formato que indicó nombres, relaciones consanguíneas (a veces), género y edad, las fechas y los lugares de partida y arribo. Algunos formatos se acompañaron de un criterio de selección clínico - tan central para el esquema de gobierno militar, así como la dedicación profesional de la población en edad laboral. No obstante, en Argentina no hay manera de rastrear oficialmente las familias que llegaron a través de alguna institución gubernamental, tampoco en el antiguo Hotel del Migrante, hoy Museo de la Migración. No obstante, allí se

\footnotetext{
18 Esta afirmación surge del trabajo de acampo adelantado tanto en el trabajo de campo en Argentina como en Guayana Francesa, donde el rasgo general cuando comentaban el paso por el campo de refugiados generalmente evocaba el silencio, y éste evocaba una complicidad colectiva sobre la experiencia de dolor. Una reflexión más profunda al respecto se encuentra en en ( Landazábal Mora, Op. Cit). los capítulos II y IV.
} 
encontró el único archivo muerto, sin clasificar, sobre los laosianos, que consistía en unas planillas sobre la llegada de los refugiados laosianos ${ }^{19}$.

Para la presente reflexión ese material conforma un punto crítico de referencia, en especial porque permite analizar el tipo de imagen que brindan los formatos oficiales para contener y administrar la información de los refugiados. La información brindada de manera específica y detallada se presenta a continuación editada, pues no cuenta con los permisos a cabalidad de la comunidad laosiana de Argentina, sin embargo, para el presente análisis, es importante pensar más allá de la información, en su imagen. Los formularios de los laosianos no estaban diligenciados a cabalidad; en los folios datan las fechas de llegada, pero nunca se completa el formato con su disposición lineal; esto deja un espacio para comprender que la espera de los países de asilo también propone vacíos, espacios para ser colmados.

El gesto que delata un formato administrativo se basa en la repetición de patrones que uniforman, una expresión consecuente con las formas de organización gubernamental. Las planillas, al organizar, homogenizan toda particularidad presente en los refugiados. Hay una asepsia de la mirada que organiza y recibe, una suerte de estructura limpia que los desvincula del caos del cual emergen y que los hace, por alguna razón, aptos para llegar al territorio argentino.

De esta manera, la repetición organizativa de la planilla asume la continuidad inaugurada en el campo de refugiados, donde se implementan estrategias para estabilizar el caos y contener lo incontenible. En contraste con otro tipo de documentos oficiales, en este material no hay firmas o alguna rúbrica que delate el conocimiento de los datos por parte del refugiado. Tampoco hay huellas dactilares -frecuentemente empleadas en los archivos oficiales estatales-; no hay señas de ningún vestigio del cuerpo, sólo información externa. Desde luego, el uso de las huellas dactilares es un motivo de reflexión y cuestionamiento, plantea a qué tipo de síntesis termina reducido el cuerpo para la organización estatal y en este caso militar, pero es un vestigio, es huella en sí misma que presume la existencia de un cuerpo; una suerte de vestigio sin rastro. No hay una huella definible más que la suposición

${ }^{19}$ Aquí, el arquitecto en jefe de la sección de archivo hizo posible llegar a estos documentos. 
de la existencia de algunas personas. Por lo tanto, aunque es la única información oficial, el refugiado asume una presencia espectral, su cuerpo es hallado al recorrer la geografía argentina y encontrar diferentes mecanismos de participación e integración en sus comunidades para hacerse visible, para buscar alternativas a las huellas inexistentes.

El hallazgo de estos documentos supone lo siguiente:

* El estado en que fueron hallados, desclasificados, en archivo muerto y sin óptimas condiciones de resguardo deja ver que la migración laosiana sólo recibió atención y seguimiento oficial de manera contingente y puntual. Después de la llegada del periodo de democratización no se visitaron estos registros y su reclasificación resultó secundaria.

* Gran parte del material se componía de fotocopias, lo que presume que hay originales de estas planillas sin organización adecuada. Las fotocopias son vestigios de los propios documentos originales y puede suponerse que hay información valiosa que los acompaña en el lugar donde estén, o que hay una parte de esa información que no ha salido a la luz.

* Junto con las planillas genéricas, aparecen fotocopias de listados extensos a cargo del Comité Intergubernamental para las Migraciones Europeas (CIME), con los nombres de las personas que arribaron, y con una serie de nomenclaturas y códigos que no se han descifrado. La saturación de estos formatos es aún más condensada que las planillas (Figura 2).

* Muchos migrantes laosianos desconocían la existencia de dichas planillas.

* Las planillas enseñan visibles errores ortográficos en la escritura de los apellidos laosianos reconocidos por los mismos refugiados tras años de estancia en Argentina, cuando lograron leer y comprender el español. Algunas familias con el mismo apellido de origen fueron separadas por errores cometidos por distintos funcionarios de los países de tránsito y de llegada, así surgieron nuevas escisiones en el contingente a la hora de organizar los destinos de asentamiento en las provincias del país de recepción.

* En consecuencia, se presume que la estrategia empleada por algunos refugiados en Tailandia para reclasificarse, fue reciclada en Argentina. El traslape continuo de 
identidades oficiales se empleó de manera frecuente para ser elegidos a segundos y terceros destinos de asentamiento; para evitar riñas internas en los campos de refugiados; o para evadir persecuciones políticas. Algunos refugiados recuerdan que era fácil hacerlo porque sabían que el reconocimiento de sus rasgos fenotípicos para 'los occidentales' resultaba difícil.

* Las edades de los infantes fueron asignadas de manera aleatoria en muchos casos. Ésta fue un requisito central para la atribución de ciudadanía. Las mujeres laosianas que llegaron siendo niñas, comentan mejor este problema al observar que después de cuarenta años de estancia, su ciclo natural de fertilidad se desfasa de la edad asignada. Con ellas, la comunidad laosiana del primer arribo mantiene en entredicho la veracidad de sus datos oficiales. Esto se debe a la pérdida de registros de nacimiento desde Laos, pero también a que muchas familias rurales tenían otros calendarios para medir la edad, y no necesariamente contaban con documentos oficiales. Al dejar a los abuelos y abuelas, la familia perdió los referentes de tiempo y con ello, el de la duración de vida.

El cuerpo de los refugiados laosianos se ha escapado del registro oficial; sin nomenclatura correcta y sin un seguimiento de resguardo. La edad es un asunto que se reconstruye en el relato de la remembranza, como un ejercicio de memoria en los diálogos colectivos. Allí, la identificación con los tiempos biográficos se observa a través de la maduración del cuerpo, con los años. Todo cambio es una nueva huella de tiempo, es un registro que debe imaginar su propia historia para actualizarse. Su cuerpo es algo que refuta continuamente el dato oficial y el documento de identificación como dispositivos de verdad.

'Lo oficial' para la comunidad refugiada laosiana en Argentina presenta un problema de imagen y reconocimiento sobre el cuerpo. A través de la información oficial se rastrean una suerte de vacíos e información no verídica; es un archivo del equívoco, y por lo mismo evoca la urgencia de las huellas. "Las planillas del Museo", como pueden llamarse esos documentos, no plantean una presencia, la ponen en entre dicho. El refugiado laosiano fue sujeto a las políticas gubernamentales. La supervivencia implicó en muchos casos perder el rastro de su pasado, o inventarlo. Sin embargo, la memoria de este tránsito no es completamente inventada, no es una memoria errante -que podría ser continua y 
silenciosa- es una memoria saturada de traslapes que condensa la pregunta por conocer qué es lo cierto; es una memoria errática. La supervivencia de la comunidad refugiada laosiana contempla un vacío que se apoya en perder el rastro para sostener la vida; pasar para vivir.

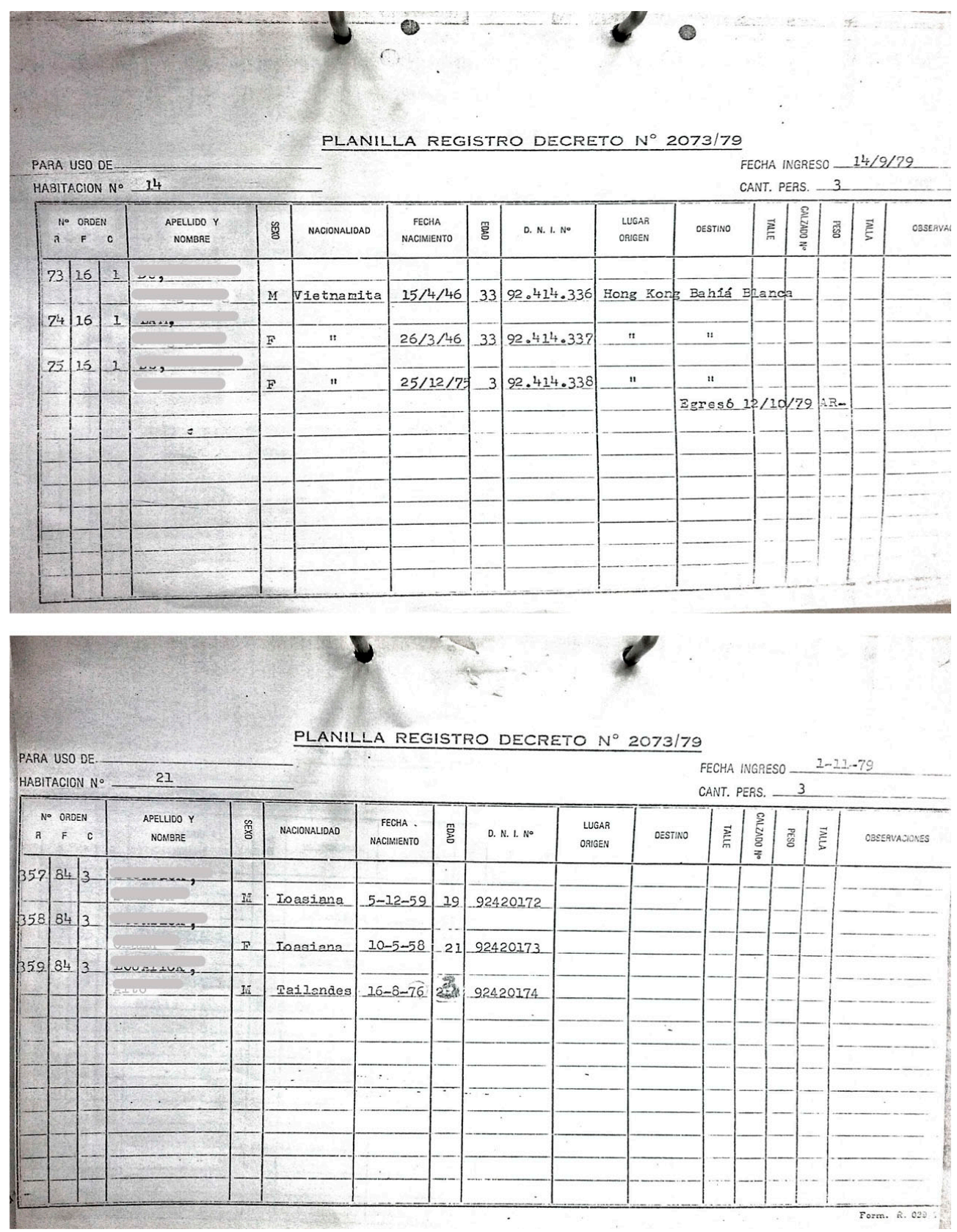

Figura 1. Planillas de registro, Decreto No. 2073/79 Argentina. Dos páginas de muestra correspondientes a las fechas de llegada de contingentes diferentes, 14 de septiembre y 11 de noviembre de 1979. Nota: Los nombres propios se ocultaron para respetar la privacidad de las personas mencionadas. 


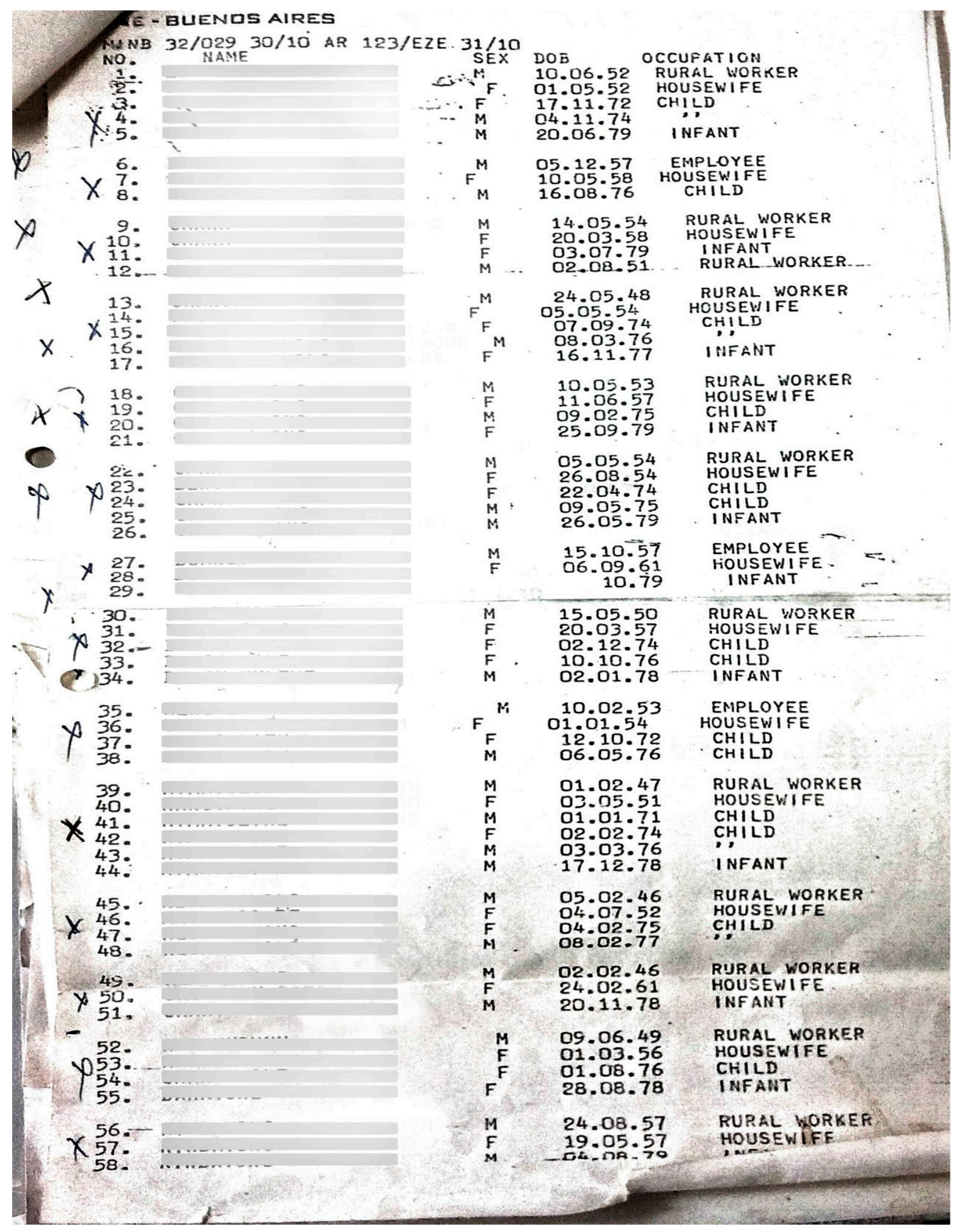

Figura 2. Planillas de registro CIME. Nota: Los nombres propios se ocultaron por respeto a la privacidad de las personas mencionadas. 


\section{b. La imagen, la prensa}

La contraparte de esta imagen de singularidades indefinidas, expuestas en documentos oficiales inciertos, lo presenta el discurso de prensa en Argentina. El uso de la fotografía documental es central para acompañar e ilustrar las notas y las crónicas que configuraron entre julio y septiembre la imagen del refugiado 'indochino'. La Nación fue el único diario que envió un corresponsal a campo y articuló un seguimiento continuo sobre el asunto de los refugiados. Las fotografías de las notas respecto al asunto de los refugiados hacían parte del acervo gráfico de la agencia estadounidense Associated Press (AP), a la cual se adscribían diferentes medios internacionales para adquirir información del mundo, sobre todo del Sudeste Asiático en la época. ${ }^{20}$ La circulación de estas imágenes en el mundo entero da cuenta del perfil homogéneo con que se caracterizaba dicha región, adscrito a la perspectiva de la narrativa estadounidense.

La imagen de los refugiados laosianos antes de convocar a la aproximación, invitaba a tomar distancia a partir de la conmoción colectiva que acompaña a la narrativa de guerra. La fotografía de víctimas y entornos de guerra se ha usado para conmover, notificar e ilustrar lo que sucede en horizontes lejanos; generalmente no se difunde en el medio del cual se extrae. Hay una deuda analítica pendiente con las imágenes circulantes de la Guerra Civil de Laos, propuestas desde allí y 'consumidas' en su contexto, pues en Occidente se desconoce cómo manejaron su propia imagen de la guerra (Hall, 2002). De esta manera, el presente apartado se centra en la fotografía que acompaña e ilustra, para comprender en rasgos generales qué estereotipo fue adosado al refugiado laosiano al interior de la sociedad argentina durante el Proceso. ${ }^{21}$

A diferencia de las planillas o formularios de registro, las fotografías de prensa enseñan una imagen basada en el aspecto físico del refugiado y así sintetizan una figura anónima que

\footnotetext{
${ }^{20}$ Véase Christian Appy, La Guerra de Vietnam, una historia oral y Bruce Franklin, Vietnam y las fantasías norteamericanas. Actualmente, la agencia ofrece el único servicio proveedor de información con base en Estados Unidos y lleva el récord más alto de premios Pulitzer para prensa.

${ }^{21}$ De la investigación mencionada, hay un análisis profundo sobre notas de prensa de Narciso Binayán Carmona. Véase ( Landazábal-Mora, $\mathrm{Op}$. Cit).
} 
perfiló la alteridad como novedad. Las fotografías de la prensa se imponen ante el espectador argentino precisamente como un público distante. El estereotipo se conforma también a partir de un patrón de repetición que origina distanciamiento, donde las matrices de lo reconocible generan comodidad en la mirada, y por ello sucede el efecto anestésico de las imágenes repetitivas. ${ }^{22}$ Este se compone de tres bases, el discurso de conmiseración, la información 'en cifras oficiales' para detallar la magnitud del fenómeno y el acompañamiento de alguna imagen coherente con el discurso como indicador del acontecimiento. El estrecho vínculo entre títulos, fotografía y pie de foto componen un complejo informativo afectivo convincente por la forma en que hace visible al refugiado. Con información permanente lo va delineando día a día, crónica tras crónica.

Se puede elaborar un hilo crítico a partir de tres estereotipos, tomados en momentos diferentes del proceso de sensibilización social de los corresponsales de La Nación para Argentina. A continuación se muestran las fotografías con su nota al pie y algunas páginas completas para observar los titulares y la composición de página. $^{23}$

\section{* Primer estereotipo}

La primera nota de prensa titulada Asistencia internacional para los Refugiados se publicó el 3 de julio de 1979 (Figura 3). Esta sería la primera nota oficial respecto al pronunciamiento de Argentina en Ginebra, para recibir familias de refugiados. La nota describe las generalidades del Canciller Pastor y su gestión ante la comunidad internacional, mientras se comenta un poco el contexto de los refugiados en el Sudeste Asiático. El pie de foto describe: 'niños vietnamitas en un campo de refugiados en una ex base aérea británica en Hong Kong’. La imagen enseña un grupo de niños, la mayoría sin camisa que miran al fotógrafo. Podrían ser niños de cualquier campo de refugiados, no hay mucho detalle en sus rostros, ni sobre el lugar. Hay que creer en la información del pie de página. Por otra parte, el papel de prensa no apoya la calidad de la fotografía, su infografía es porosa, disponible para toda interpretación que ajuste el titular de la

\footnotetext{
${ }^{22}$ Una reflexión profunda sobre el uso de la imagen en momentos de guerra y catástrofe la propone el artista suizo Christoph Draeger, quien explica cómo la matriz del desastre se hace patrón de consumo en los medios masivos. Véase el podcast del 15 de julio de 2016, del Museo de Arte Contemporáneo de Barcelona https://rwm.macba.cat/es/sonia/sonia-228-christoph-draeger.

${ }^{23}$ Nota: por motivos de formato de la presente edición, las columnas de lectura no son visibles, ya que las páginas en tamaño real son de pliego, sin embargo se pueden apreciar los títulos y la composición general del diseño de página como guía visual del análisis.
} 
noticia. Finalmente el rasgo común se centra en el fenotipo de los pequeños, detallando sus rasgos asiáticos, que los funden en el estereotipo 'oriental y bélico' del momento.

Al mirar en retrospectiva esta página de prensa, se encuentran elementos determinantes para comprender el juego simbólico que proponía a diario la información mediática ante el público lector (Figura 4). En la parte superior derecha, la fotografía de niños refugiados confronta al subtítulo publicitario 'Estética corporal' seguido por otros recuadros de propaganda donde destaca la repetición de la palabra 'RIO'. Esta publicidad buscaba incentivar actividades agrícolas en la provincia de Río Negro - lugar al que serían destinadas algunas familias de refugiados posteriormente y el cual, por sus condiciones climáticas representó un desafío para la adaptación. Debajo de la fotografía, otro titular anuncia 'Atentados en Bolivia'.

La composición de la página detalla una sintaxis de contraposición. Son diferentes registros de información compitiendo por un lugar de visibilidad, pero a la vez, proponen una jerarquía de los fenómenos sociales y del acompañamiento simbólico-comercial que ameritan. Así, deb entenderse la situación de 'la estética' en un tercer lugar, a 'Bolivia' en segundo y a los refugiados, sobre quienes recae la 'bondad' del gobierno argentino, en primero. Se expresa enfáticamente el interés por construir una imagen pública positiva del Proceso, a costa de la gestión de los refugiados representados en niños de cualquier parte. Una de las estrategias frecuentes en las notas sobre la gestión de recepción consistió en la comparación informativa en detrimento de otros contextos suramericanos, destacando la labor humanitaria argentina.

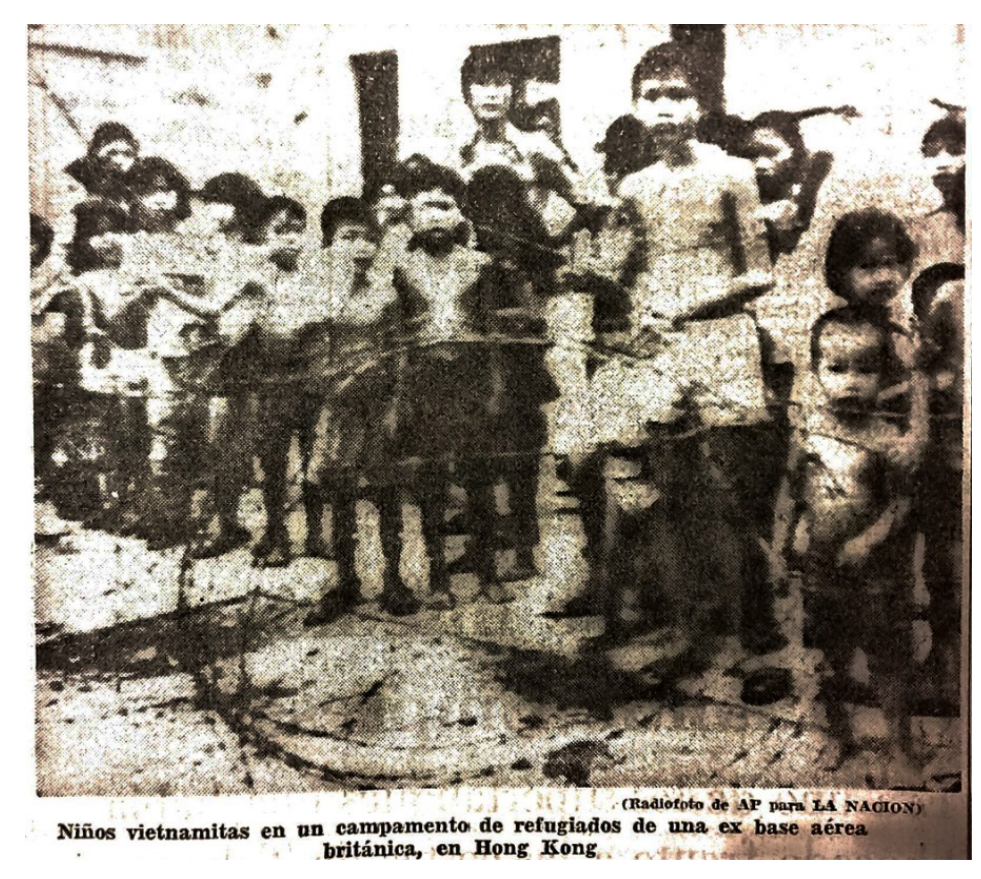


Figura 3. Fotografía de AP tomada de La Nación, 3 de julio de 1979 'Asistencia internacional para los refugiados'. Pie de foto: Niños vietnamitas en un campamento de refugiados de una ex base aérea británica en Hong Kong.

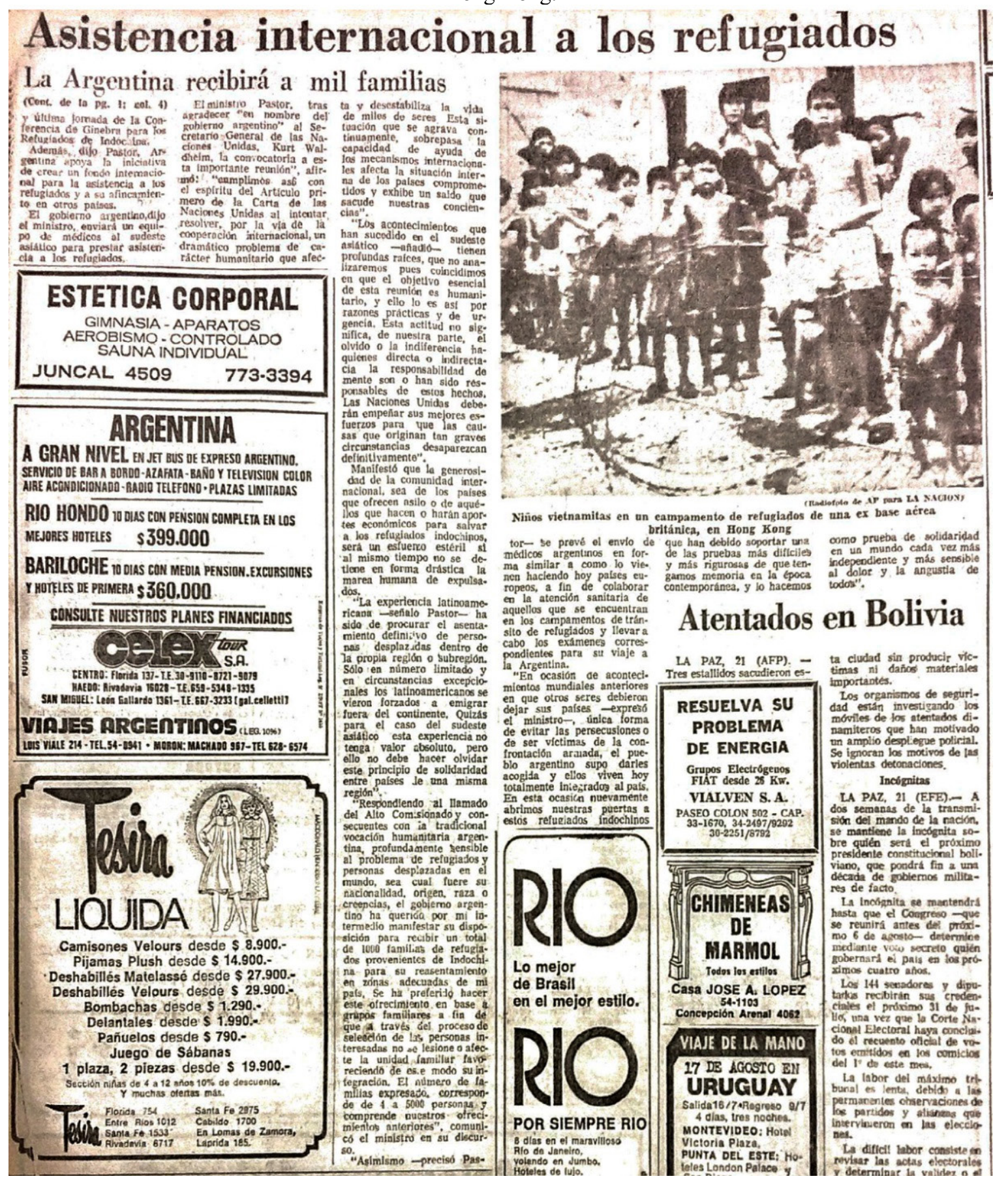

Figura 4. Página tomada de La Nación, 3 de julio de 1979 ‘Asistencia internacional para los refugiados’. 


\section{* Segundo estereotipo}

La segunda fotografía, publicada el 24 de julio de 1979, acompaña la nota de prensa del corresponsal de La Nación en París - un punto geográfico determinante para el paso de información del Sudeste de Asia hacia Argentina. La fotografía encabeza la nota de prensa de Luis Mario Bello titulada El problema de fondo subsiste (Figura 5). La imagen enseña un grupo de niños sonrientes, también descamisados -quizá en correspondencia con una crónica precedente de Narciso Binayán Carmona quien destacó 'la alegría' de los niños refugiados en momentos adversos. El pie de foto describe: 'niños refugiados vietnamitas en una playa cercana al campo donde se los alojó al Sur de Tailandia'; tomada de Associated Press Photo.

De nuevo, se debe creer en el pie de imagen, éste se comporta como geografía de referencia. La triada título, ubicación del corresponsal, fotografía y pie de foto conforman un conjunto que describiría el problema en sí mismo; lo que subsiste es la precariedad de la infancia. Sin embargo, la nota expresa de manera abierta el interés de Argentina por destacarse ante la comunidad internacional, donde afirma: "puede ser que la formalización de ese proceso desdibuje en gran parte la mala imagen de la Argentina, difundida en el extranjero". De manera directa el corresponsal cuestionó a otros países latinoamericanos por no responder al llamado de las Naciones Unidas para recibir refugiados del Sudeste Asiático. Denuncia la retirada de ayuda de Costa Rica, la evasión de México y Brasil para ofrecer ayuda, y por último denuncia la actitud de Venezuela, al ofrecer sólo ayuda económica a los refugiados, pero no de asilo.

Por otra parte, el diseño de la página se concentra en el contrapunto de dos artículos dedicados al problema del Sudeste Asiático. El primero titulado Después de la huida, el vietnamita vive como un paria, a la izquierda de página y la nota en mención a la derecha, dentro de la Sección llamada El problema de los refugiados, qué semanas después se denominó El drama de los refugiados (Figura 6). Un titular más pequeño a mitad de página, y en la parte inferior informa Condenarán a la horca a 330 turcos. 
El contenido de la página es dramático, se concentra en detallar los fenómenos bélicos más importantes del escenario internacional. En este sentido, el efecto de conmoción invoca el apoyo del lector ante la gestión humanitaria. Es una manera de sensibilizar al ciudadano local para disponer la recepción y aceptación del nuevo grupo migrante y para asimilar, de manera positiva, la gestión del gobierno del Proceso de Reorganización Nacional.

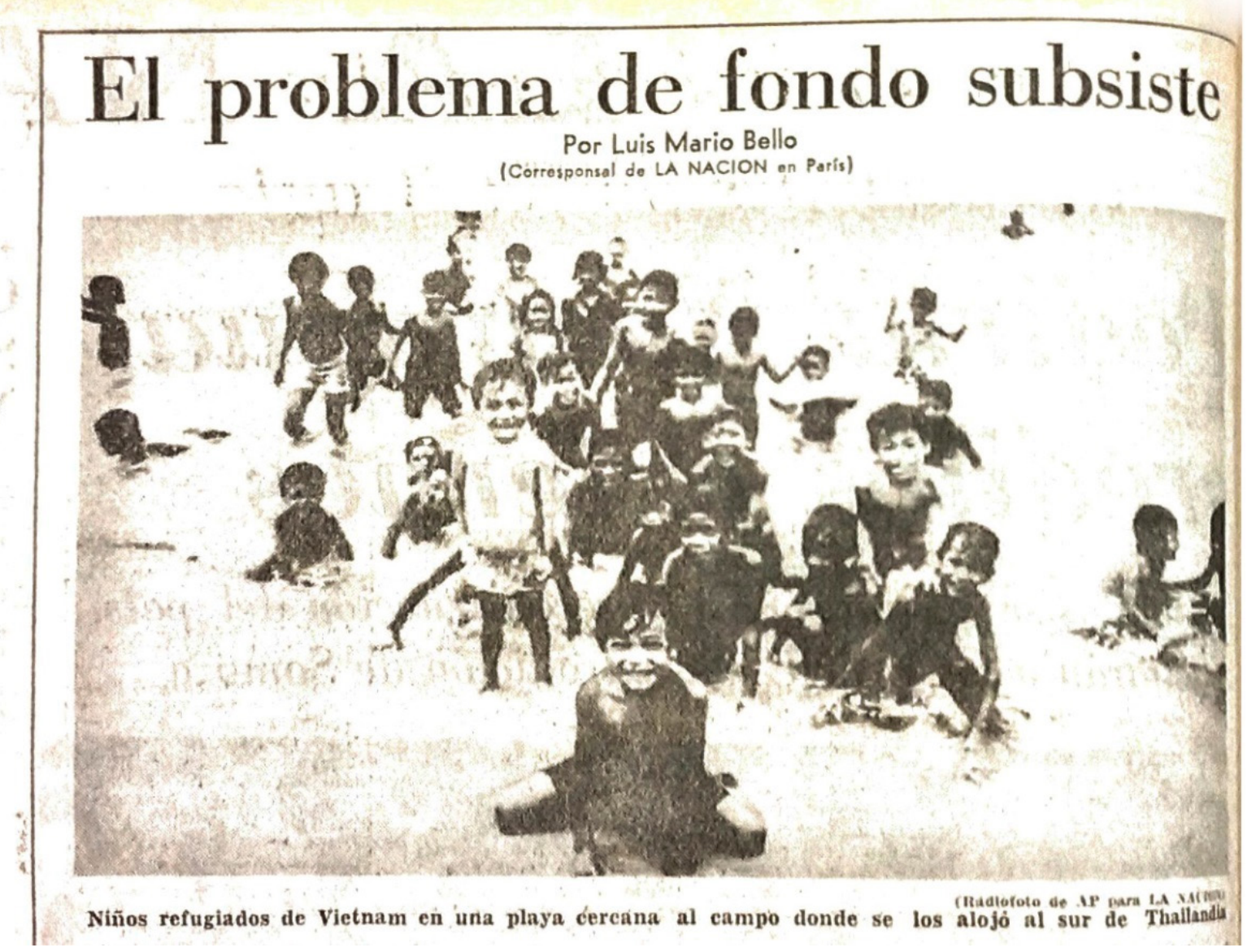

Figura 5. Fotografía de AP, tomada de La Nación, 24 de julio de 1979 'El problema de fondo subsiste', por Luis Mario Bello. Pie de foto: Niños refugiados de Vietnam en una playa cercana al campo donde se los alojó al sur de Tailandia. 


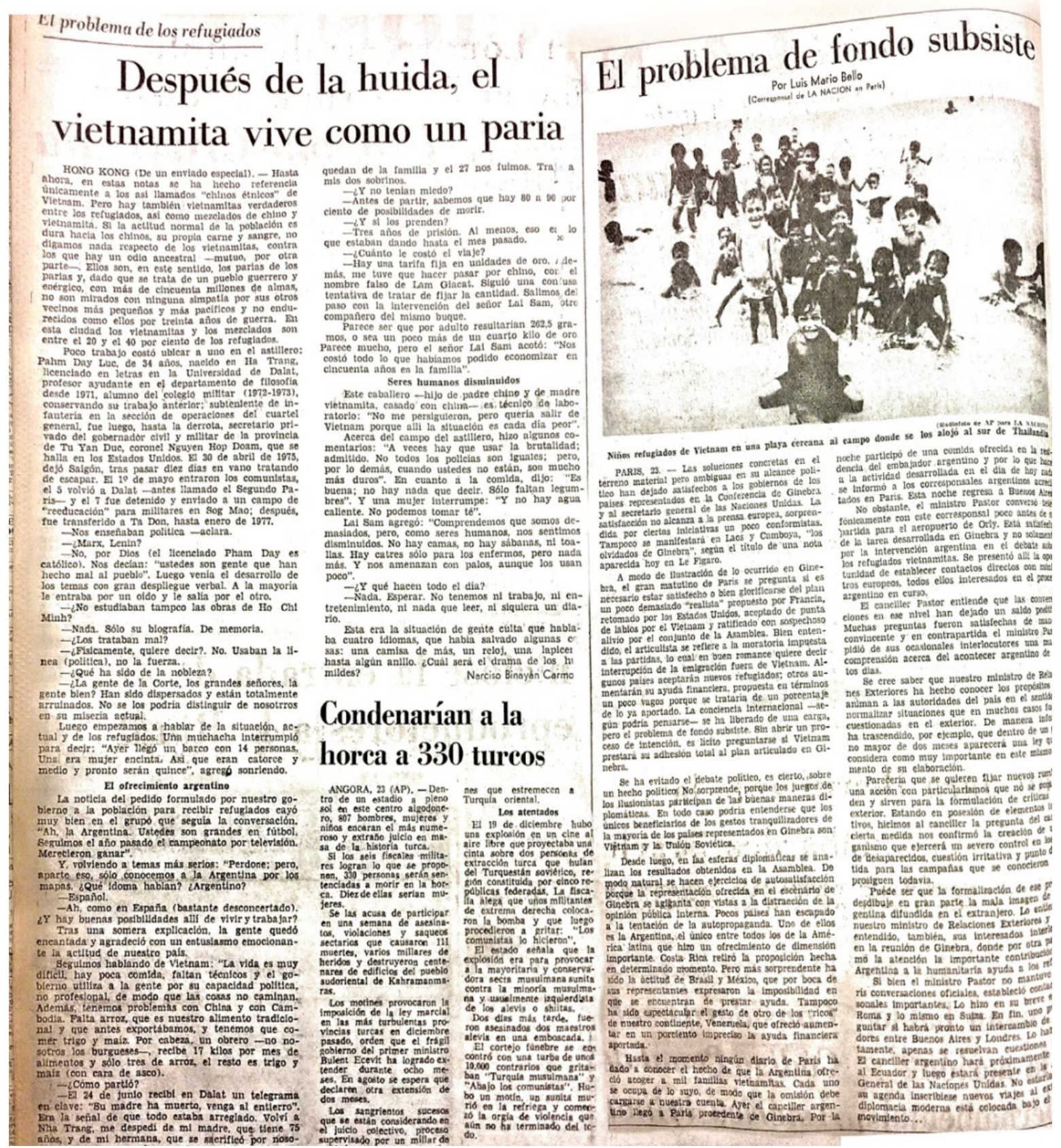

Figura 6. Página de La Nación del 24 de julio de 1979. 


\section{* Tercer estereotipo}

Por último, la portada del 15 de septiembre de 1979 anuncia su primer titular Están en el país los primeros refugiados, seguido de una fotografía de una multitud de personas infantes y adultas y en primer plano un niño con una bandera pequeña en su mano derecha (Figura7). El pie de foto describe: "Para este niño vietnamita, Ezeiza es el desconcertante umbral de una nueva manera de vida. Lleva consigo los símbolos del país que lo acoge y en la mano izquierda el misterioso complemento de sus primeros pasos por la tierra que ya es su hogar".

La imagen del niño está explicada por el pie de foto, donde una vez más se alude a una nacionalidad de origen aleatoria, pero se hace visible la bandera argentina, como evidencia de un mecanismo de asimilación localizado. La descripción idílica del encuentro de una nación de asilo acompasa el acontecimiento con la descripción del periplo de los migrantes. La figura del infante, se antecede por un subtítulo donde informan que, de las 89 personas que llegaron 39 fueron niños. El enunciado da cuenta de la intención por exponer a la población infantil como una generación puente entre sus padres y las costumbres argentinas. La bandera implica muy poco para el niño, quien aún no construye un sistema de identificación con ella, pero funciona para el público local que debe entender en esa imagen un recibimiento afectivo.

Por su parte, el diseño de portada expresa de manera radical el traslape informativo que se buscaba ante la visita de la CIDH. A la derecha del titular mencionado, en una columna muy delgada, otro titular Bignone informó a Videla, referente al informe solicitado para comprender la percepción social sobre la visita de la CIDH; a la derecha de esta breve nota, y ocupando también casi la mitad de la página figura Graves incidentes en El Salvador. Inmediatamente abajo a la derecha Nuevos actos de violencia en Colombia, y a la izquierda de este titular Mantiénese la tensión social en Brasil. Cerrando el círculo informativo, bajo el titular de los refugiados, se anuncia La comisión de la OEA (Figura 8).

La página completa es un mapa de navegación para comprender el uso de los recursos de prensa por parte del gobierno del Proceso. Si bien, dicha lógica funcionó a lo largo de los meses datados, esta página reúne las características centrales: contrapeso informativo, 
comparación en detrimento de países de la región y exaltación de la gestión del gobierno argentino. Es notable el lugar estratégico que se reserva en la columna de la mitad para reforzar la información solicitada por el General Jorge Rafael Videla. La gramática empleada en esta página consistió en configurar una imagen positiva del Proceso a través del contraste y el uso informativo de noticias bélicas de otros países. Al interior del articulado de la prensa, la noticia de los refugiados se desarrolla en la página 16. Allí se encuentran más imágenes que hacen explícita la presencia de los refugiados. Las tres fotografías enseñan grupos de infantes, mujeres y un hombre adulto joven, detallando gestos amistosos de la recepción.

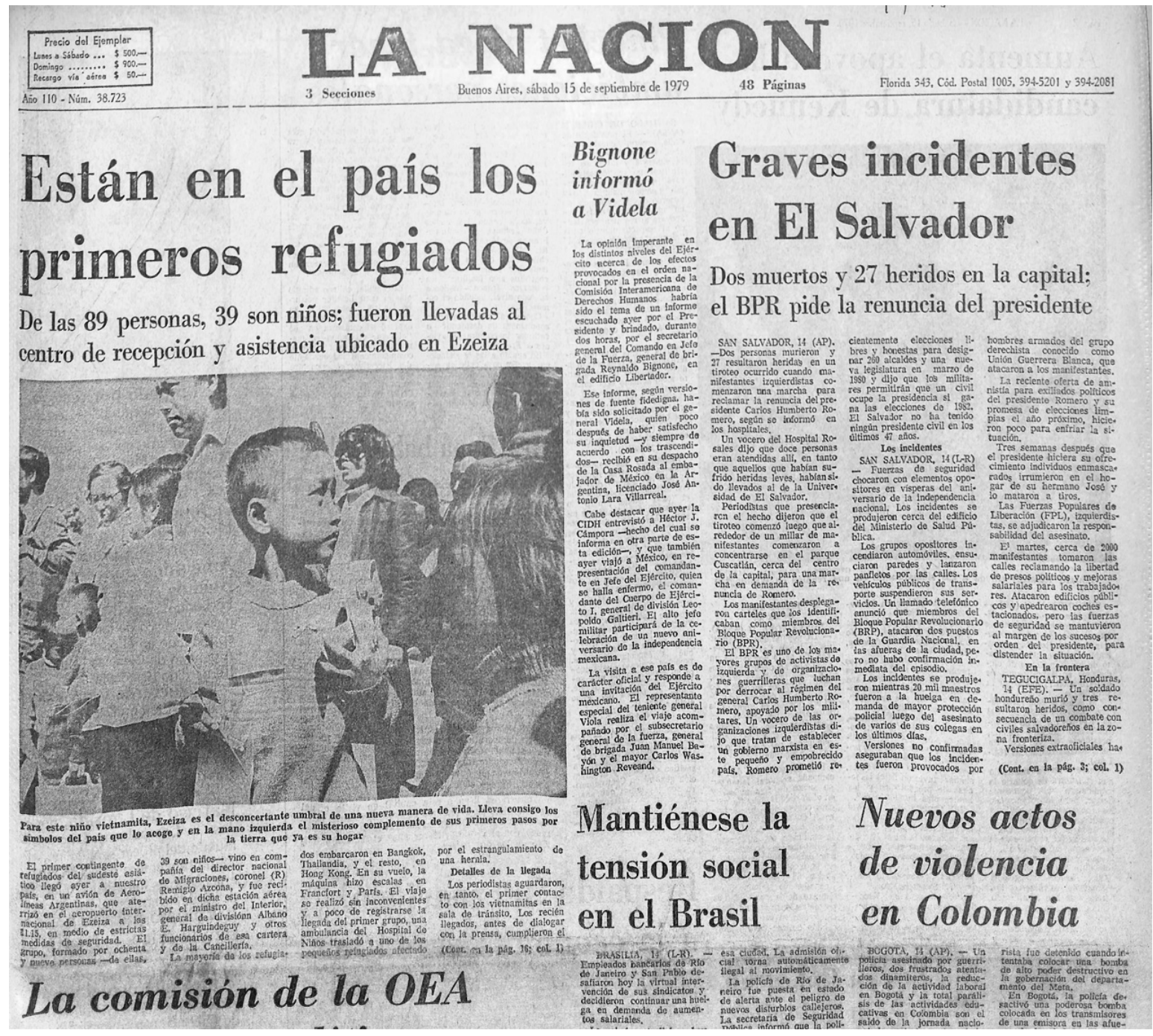

Figura 7. Portada de La Nación, 15 de septiembre de 1979. 


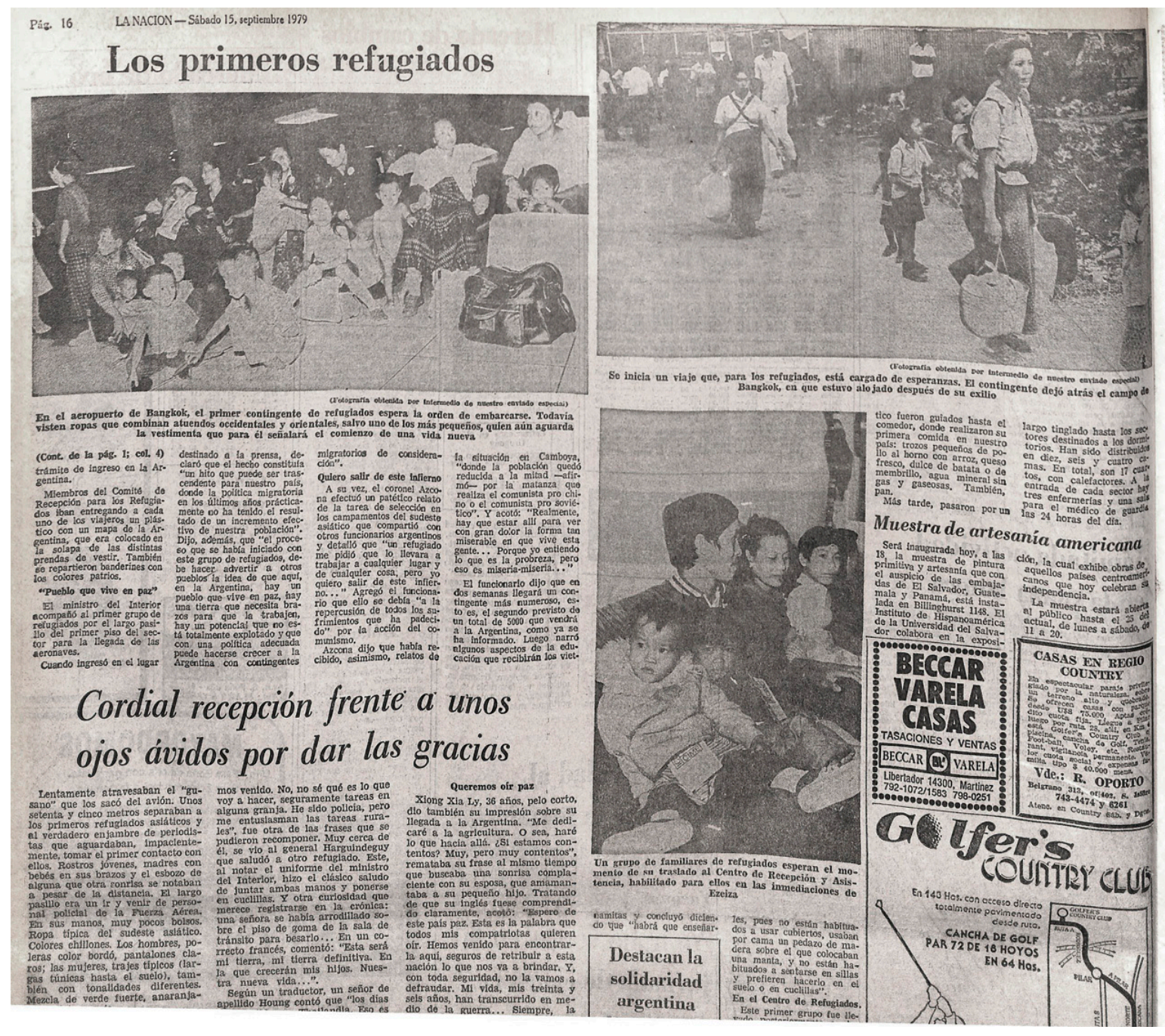

Figura 8. Página 16 de La Nación, continuación noticia de portada, del 24 de julio de 1979.

Puede verse en los ejemplos citados que la complejidad de la geografía política del Sudeste Asiático quedó traslapada en el estereotipo de sesgo marginal y fenotípico de las poblaciones involucradas en el conflicto. La orientalización de los refugiados se usó como propulsor de información sobre la guerra de Vietnam y derivó en desconocimiento de los conflictos internos de su lugar de origen. Se difundió ampliamente el imaginario de vietnamitas, y posteriormente el de indochinos, pero en la historia argentina son los propios contingentes quienes han detallado su imaginario como laosianos. Ahora bien, siguiendo la lógica geográfica y el contrapunto expuesto en la información, nunca se mencionó en alguna nota argentina el asilo que brindó la Guayana Francesa en 1977 y luego en 1979 a 
refugiados laosianos dentro de los análisis regionales, quizá porque esta región ha sido tradicionalmente percibida como una adenda europea. Aunque este asunto no se desarrolla en el presente artículo, conviene traerlo a presencia para comprender por qué la migración laosiana no es visible en la región.

La imagen del estereotipo del refugiado adecúa políticamente las diferencias en el marco de lo visible como principio de relación. Avtar Brah explica que el estereotipo habla de una forma de imaginar, pensar y tratar al otro basado en el aspecto (Brah, 2011). Este tratamiento lo reciben de manera frecuente los migrantes en cualquier parte del mundo. Sobre el refugiado pesa su situación política y económica, y para el caso laosiano en Argentina, su condición ancestral vinculaba al campesino y al indígena orientalizado con rasgos 'primitivos'. De esas imágenes de prensa destacan el género y la edad, ya que las mujeres laosianas con sus niños en brazos ayudaban a configurar el formato de la precariedad.

La imagen de la infancia refugiada propone un paralelo con la imagen de infancia que pretendía difundir el Proceso. Durante aquel periodo se emplearon slogans de propaganda como "Juventud, realidad de hoy, esperanza del mañana" que buscaban crear en la juventud rasgos de adhesión a las prácticas militares. ${ }^{24}$ El adiestramiento social se apoyó en la configuración de imágenes de una juventud ejemplar que sirviera para la contrainsurgencia. Un contraste del abuso de imagen de infancia corresponde al caso de Alejandrina Barry, una niña de tres años, hija de militantes uruguayos capturados que paseó por los diarios argentinos bajo titulares como 'Los hijos del terror' ó 'Alejandrina está sola'. ${ }^{25}$ Su imagen sirvió como escarmiento para ilustrar sobre las "nefastas consecuencias" que dejaba la acción insurgente, planteada como un acto irresponsable con las generaciones venideras.

En este marco, los refugiados laosianos víctimas de la persecución comunista en su entorno originario fueron pieza clave para países occidentales en el escenario de la Guerra Fría. Sin

\footnotetext{
${ }^{24}$ El slogan hace parte de un conjunto de propaganda de dictadura donde se convence a las generaciones más jóvenes para integrarse a las fuerzas armadas. Véase https://www.youtube.com/watch?time continue $=29 \& \mathrm{v}=7 \mathrm{H} 146 \mathrm{~g} 3 \mathrm{ycUs}$

${ }^{25}$ Véase los artículos de las siguientes revistas: "Los hijos del terror"; enero 5 de 1978 en Gente, titulado "Esto también es terrorismo. Alejandra está sola" y Para Ti enero 16 de 1978 con el título "A ellos no les importaba Alejandra".
} 
embargo, esta información no se explotó en el discurso de prensa argentino, pesó más la imagen de víctima de guerra. La gestión llevada a cabo por la Comisión Católica para las Migraciones se apoyó en la conmoción de esta información para organizar campañas de reasentamiento en apoyo a los refugiados laosianos que se devolvían de otras provincias, algunos extraviados y otros en busca de auxilio a Buenos Aires.

La imagen del refugiado, en tanto sujeto de todas las excepciones jurídicas y políticas, acondiciona una serie de expectativas que lo (in)capacitan para ser incluido en la nueva sociedad. La infancia refugiada no sólo representa el eslabón más débil de las víctimas a nivel físico, sino que conjuga la posibilidad de sincronizar la "nueva memoria" con el futuro, con 'el ciudadano del mañana'. La infancia laosiana en perspectiva estatal dispuso una masa amoldable donde el colectivo de refugiados fue infantilizado: 'no entienden el español'; 'no saben hablar, no tienen las costumbres, requieren ser asistidos'; en suma, deben ser reeducados para ser asimilados.

Por otra parte, la imagen de la infancia refugiada importa por su potencial simbólico, por la posibilidad de adhesión al territorio de llegada. Ninguna de las fotografías de niños y niñas registra sus nombres, apellidos o apodos, 'los niños' siempre son referenciados en plural. Los registros oficiales impostaron la edad de la mayoría de infantes y las estrategias de alfabetización no acompañaron su integración a la comunidad local. No obstante, la esperanza del futuro laosiano en Argentina se trabaja en del discurso de la infancia, como una promesa. Con la desconfiguración de los documentos oficiales y el discurso mediático se dan las primeras bases para caracterizar la población laosiana adulta de la actualidad. A la memoria de guerra y exilio -abordada por ellos como una memoria imaginada y mítica, la sucede la memoria vivida del difícil asentamiento; esta parte ha estado fuera del discurso de prensa y del oficial.

\section{Reflexión final: para una cartografía del imaginario-archivo}

El imaginario-archivo reconoce que toda huella pasa; está supeditada a la condición agónica del tiempo. De manera que se comprende en tanto archivo de la im-permanencia. Los refugiados han consignado en su diáspora un tránsito de miles de kilómetros que 
conjunta diferentes temporalidades de las cuales se han perdido la mayor parte de vestigios; sean los saberes de los abuelos y abuelas, los trajes tradicionales, las prácticas de cultivo originarias, las lenguas o los documentos oficiales. De ahí la importancia de establecer las correspondencias entre imagen-imaginario y la capacidad para imaginar de manera política, resignificando y refuncionalizando el pasado.

El refugiado de guerra es poseedor de una imagen que pesa, su status político sigue vigente de manera simbólica y acompañará a su comunidad heredera junto a los patrones fenotípicos. El peso de esa imagen de prensa, que habla de una huella genética no desaparece prontamente. Esta herencia yace en el conjunto de valores y prácticas que le otorgan distinción, desde allí formula su debate con la apariencia. El peso simbólico del status refugiado perdura más que los atributos jurídicos, y su rastro da cuenta de una serie de trayectos y mecanismos que lo actualizan de manera constante en cada entorno de recepción.

Hay diferentes hilos sueltos en ese denso entramado de la diáspora laosiana. Todo el cúmulo de imágenes dominantes que instauraron su presencia partiendo de técnicas fotográficas y mediáticas, facultadas por los aparatos políticos institucionales, produjo un modo específico de imaginar al refugiado indochino. Habría que comprender tales indicios como 'imágenes técnicas' adormiladas, que han sobrevivido a diferentes catástrofes de la reconstrucción del tiempo y se comportan como una suerte de cajas negras, tomando la expresión de Vilem Flausser. ${ }^{26}$ Mientras abastecen el almacén de una memoria soterrada, son también vestigio. Tienen la capacidad de hacer que ese "algo" que es la migración de los refugiados laosianos se vuelva imaginable, y esta es la cualidad principal para comprenderlas como archivo.

Ahora bien, el imaginario-archivo propone un entramado de discursividad y de visibilidad de imágenes acompasadas a la fuerza -infantes refugiados, las planillas oficiales, crónicas de prensa. Todos estos vestigios o indicios son síntomas de otra narrativa, la del

\footnotetext{
${ }^{26}$ Según el teórico checo-brasilero, comprender las imágenes técnicas como "cajas negras" abre por una parte la visión a comprender que hay un banco de imágenes encriptado, soterrado, y que éste mismo puede sacarse a la luz para esclarecer pautas del pasado. esto, para el autor es la revisión crítica de las imágenes, sacarlas de la mirada objetiva, para comprender la visión. Véase (Flusser, 1990).
} 
imaginario. Este atiende el universo de tensiones políticas y simbólicas que recaen sobre dichas imágenes, pero más aún, sobre los cuerpos que estas ocultan, sobre la presencia y vigencia de los refugiados como sujetos políticos.

El imaginario-archivo se adscribe a un horizonte bifurcado. Mientras que el archivo procura imágenes concretas, el imaginario coloca en tensión todo lo que no es imagen. El imaginario-archivo busca en el campo de lo no visto, de lo olvidado o que quedó sedimentado, vestigios que atraviesan el presente y resignifica el pasado; así coloca en tensión presente y futuro dentro de la capacidad imaginaria.

El imaginario-archivo propone concretar una lógica de aparición distinta, la de una inscripción en la memoria, no como una traza dispuesta y evidente, sino como huella, en el sentido de Patrick Chamoiseau. La huella tiene por su parte esa condición falible de desaparecer, pero en tanto ente político, se opone al monumento, al pasado petrificado. Por lo tanto, este imaginario-archivo es un acervo simbólico siempre actualizable; es una estructura abierta. Proponerlo como cartografía coloca en tensión su topografía y la temporalidad de esta junto con otros trayectos de la diáspora laosiana. Esas rutas exceden el territorio de la imagen de prensa, de los estatutos jurídicos, de los marcos de memoria y en general rebasan la geografía Argentina para conectarla con las huellas de otra memoria, la de la amplia red de la diáspora laosiana, la de la memoria compartida entre el Sudeste Asiático y América Latina. 


\section{REFERENCIAS}

ACNUR. "The State of The Wolrd's Refugees 2000 : Fifty Years of Humanitarian Action.” [2000]. Consultado Abril de 2018. http://www.unhcr.org/3ebf9bad0.html

APPY, Christian. La Guerra de Vietnam. Una historia oral. Barcelona: Crítica, 2012.

AGAMBEN, Giorgio. "We Refugees.” Symposium A Quarterly Journal in Modern Literatures, 49:2, (1995): 114-119.

BALÉ, Cinthia, « Usos del archivo y políticas de la memoria: un análisis del proceso de "apertura" de los archivos militares en Argentina (2003-2015) », Nuevo Mundo Mundos Nuevos. décembre 2018, consulté le 29 janvier 2020. URL: http://journals.openedition.org/nuevomundo/73860 ; DOI : 10.4000/nuevomundo.73860

BRAH, Avtar. Cartografías de la diáspora. Identidades en cuestión. Madrid: Traficantes de sueños, 2011.

CALVEIRO, Pilar "Los usos políticos de la memoria", en Gerardo Gaetano (comp), Sujetos sociales y nuevas formas de protesta en la historia reciente de América Latina, Buenos Aires: CLACSO, 2006.

CASTILLEJO, Alejandro; Albarracín Reyes Fredy Leonardo. Violencia, memoria y sociedad: debates y agendas en la Colombia actual. Bogotá: Universidad Santo Tomás USTA, 2013.

CHAMOISEAU, Patrick, Guyane, traces- mémoire du bagne. Paris: Caisse Nationale des Monuments Historiques, 2002.

DAO, Yang. Hmong at the turning point. Minneapolis: World Bridge Associates, 1993

DERRIDA, Jacques. Mal de archivo. Una impresión freudiana. Madrid, Editorial Trotta, 1997 
DIRECCIÓN NACIONAL DE POBLACIÓN. Refugiados del Sudeste asiático en la Argentina: 30 años de historia. Argentina: Ministerio del Interior, 2012.

ESCOBAR, Arturo. Otro posible es posible. Caminando hacia las transiciones desde Abya Yala/Afro/Latino-América. Bogotá: Desde Abajo, 2018

FLUSSER, Vilém. Hacia una filosofía de la fotografía. Ciudad de México: Trillas, SIGMA, 1990.

FOUCAULT, Michel, La arqueología del saber. Buenos Aires: Siglo XXI, 2002. . Las palabras y las cosas. Ciudad de México: Siglo XXI, 2010.

FRANKLIN, Bruce. Vietnam y las fantasías norteamericanas. La Habana : Editorial de Ciencias Sociales, 2016.

HARRISON-HALL, Erika. Vietnam, behind the lines. Images from the war 1965- 1975. Londres: The British Museum Press, 2002.

LANDAZÁBAL-MORA, Marcela. "Lo que resiste entre el exilio... Una genealogía de la diáspora laosiana en Guayana Francesa y Argentina.” Tesis de Maestría. México. UNAM, 2019

NAZAR, Mariana, "Dictadura, archivos y accesibilidad documental. A modo de agenda" en Centro de Estudios Legales y Sociales, Derechos Humanos en Argentina. Informe 2007, Buenos Aires, EUDEBA, 2007.

NORA, Pierre. Pierre Nora en Les lieux de mémoire. Montevideo: Ediciones Trilce, 2008.

ONAHA, Cecilia. "Historia de los inmigrantes japoneses en Argentina. Inmigrantes libres y la formación de la comunidad japonesa." Tesis doctoral. Kyoto: Universidad de Posgrado de Estudios Avanzados, 1997.

REDONDO, Adriana. “Análisis de la integración cultural de los refugiados laosianos en la Argentina", En Revista de Estudios migratorios latinoamericanos. No. 5, Año 2. Buenos Aires. Abril de 1987. 
RUFER, Mario. "El archivo, la fuente, la experiencia". Epistemologías del Sur. Buenos Aires- Coimbra; CLACSO, 2018.

SILVA, Renán. "Memoria e historia: entrevista con François Hartog. En Historia Crítica No. 48. Bogotá. Septiembre- Diciembre 2012; pp 208 - 2014.

THAWEESIT, Suchada. "Narraciones sobre la legitimidad, narraciones sobre la capacidad de actuar: las negociaciones para obtener la ciudadanía entre los laosianos internacionalmente desplazados en el noreste de Tailandia". En La antropología de las fronteras en Tailandia como espacios de flujo, coordinado por John Marston, 165-195. Ciudad de México: CEAA-COLMEX, 2016.

VEZZETTI, Hugo. Pasado y presente. Guerra, dictadura y sociedad en la Argentina. Buenos Aires: Siglo XXI, 2003.

YAO, Jean Arsène «Negros en Argentina: integración e identidad », Amnis [En ligne], $2 \mid 2002$, mis en ligne le 30 juin 2002, consulté le 30 janvier 2020. URL: http://journals.openedition.org/amnis/183; DOI : 10.4000/amnis.183

ZULPO, Romina. "Memoria e identidad. Del Sudeste de Asia a Posadas." Tesis de Licenciatura en Antropología social. Posadas. Universidad Nacional de Misiones, 2012.

Recebido: 31/01/2020

Aprovado: $15 / 07 / 2020$ 